Marquette University

e-Publications@Marquette

Spanish Languages and Literatures Research and

Languages, Literatures and Culture Faculty

Publications

Research and Publications

$12-1-2014$

\title{
An Organic Nation: State-Run Tourism, Regionalism, and Food in Spain, 1905-1931
}

Eugenia Afinoguénova

Marquette University, eugenia.afinoguenova@marquette.edu

Published version. The Journal of Modern History, Vol. 86, No. 4 (December 2014): 743-779. DOI. (C) 2014 University of Chicago Press. Used with permission. 


\title{
An Organic Nation: State-Run Tourism, Regionalism, and Food in Spain, 1905-1931*
}

\author{
Eugenia Afinoguénova \\ Marquette University
}

\begin{abstract}
Because he was the local representative of the absentee political boss and was himself a big chief in the village, he felt that insulting the good name of the country was the same as slyly criticizing its politics. . . "Well, we've developed more substantial, more beneficial things," he said, placing his open palms over his stomach- - "Galician stew, Asturian pork and beans, codfish a la Vizcaina, Valencian paella, Mallorcan baked sausage, not to mention chorizo and the Jesuits. And, of course, we can't leave out the discovery of the New World.” (Ramón Pérez de Ayala, Belarmino and Apolonio, 1921)
\end{abstract}

In 1905, Spain became the first nation in the world to establish a government agency responsible for tourism: the National Commission for the Development of Artistic and Leisure Excursions of the Foreign Public. ${ }^{1}$ At that time, hardly anyone could foresee that this would be the dawn of a new era - one in which Spain would find itself among the world's top travel destinations. ${ }^{2}$ Citing the lack of "private initiative" and the weight of "carelessness and apathy, daughters of our national character," the text of the foundational decree made it clear that Spaniards were so ill-equipped for the hospitality business that the state simply had to step in. ${ }^{3}$ Tourism "from above" was a peculiar experiment for its time, but it put Spain ahead of countries with better-developed destinations, such as France,

*The archival research for this article was funded by a Regular Research Grant from Marquette University and by the Robert and Mary Gettel Research Fund. The author wishes to thank Elizabeth "Betsy" Boone, Sally Anna Boyle, Sarah Davies Cordova, Sasha D. Pack, Eric Storm, and the journal's anonymous readers for their thoughtful and extremely helpful comments.

${ }^{1}$ Comisión Nacional para fomentar las excursiones artísticas y de recreo del público extranjero, 1905-11.

${ }^{2}$ According to UNWTO world tourism rankings, Spain is currently the world's fourth in international tourism arrivals (after France, the United States, and China), and it is second in revenue from inbound tourism (after the United States).

3 "Real decreto creando una Comisión Nacional encargada de fomentar en España las excursiones artísticas y de recreo del público extranjero," October 6, 1905, Gaceta de Madrid, no. 280, October 7, 1905; my translation here and throughout, unless specifically stated.

The Journal of Modern History 86 (December 2014): 743-779

(C) 2014 by The University of Chicago. $0022-2801 / 2014 / 8604-0001 \$ 10.00$

All rights reserved. 


\section{Afinoguénova}

Italy, and Switzerland. ${ }^{4}$ In the years that followed, Spanish officials faced the daunting task of organizing tourism even as they were still trying to understand the meaning of "tourism" itself. If the state ultimately became a faithful stakeholder in this emerging industry, it was the result of one early discovery: that organized travel was not just an economic activity but also a powerful identity maker and therefore a tool for building the nation.

A country of traditionally strong local loyalties and weak national ties, in the early twentieth century Spain was a nation still under construction. The regions that had enjoyed a considerable degree of autonomy under the old regime were demanding their own statehood. Other groups claimed that they did not fit culturally or linguistically. Although between 1902 and 1931 the country's political regimes were drastically changing - from King Alfonso XIII's liberal monarchy (1902-23) to Miguel Primo de Rivera's dictatorial regime in support of that monarchy (1923-31) to the Second Republic in 1931 - no administration could implement any program without first addressing the question of how, if at all, it would integrate the communities forming part of its territory. Different social groups disagreed about the best ways of achieving national cohesion and the details of what that cohesion would look like, fueling a continuous public debate about nation building. The enthusiasts of state-run tourism came from the educated upper classes. Residents of Madrid yet patriots of what they called "small motherlands," the patrias chicas of their birth, they were keen to teach the "old dog" of the Spanish state some new and periphery-friendly tricks. In their hands, tourism became a force for harmonizing subnational patriotisms.

As this article will demonstrate, the success of state tourism was predicated on two important concepts developed earlier by the teachers of Spain's first tourism administrators, known as Krausistas. In the last quarter of the nineteenth century, these philosophers and social reformers redefined nations as "organic" agglomerations of strong regions marked by centripetal as well as centrifugal forces. They also claimed that works of genius alone could not guarantee a nation's vitality - it would need to be revived and maintained by its rural lower and middle classes producing embroidery, pottery, vernacular architecture, and local food. Educated in the Krausista spirit, the designers of twentieth-century policies took the emerging tourism business and redefined it to promote this notion of cultural nationhood. In what follows, I examine Spain's early tourism as a political tool and argue that the officials and their partners in the regions used the daily activities of peripheral rural communities in order to craft, from the center, regional identities that could fit together and form a renewed competitive nation.

\footnotetext{
${ }^{4}$ Luis Fernández Fúster, Historia general del turismo de masas (Madrid, 1991), 212; Carmelo Pellejero, "Antecedentes históricos del turismo en España," in Historia de la economía del turismo en España, ed. Carmelo Pellejero (Madrid, 1999), 23-25.
} 


\section{Introduction: Regionalism, Centralism, Tourism}

The government of each political regime that came to power in Spain in the early part of the twentieth century had to address Basque and Catalan (and, to a lesser degree, Galician and Valencian) claims for self-determination. Tourism was called upon to build on the Spaniards' attachment to their native lands while simultaneously promoting a sense of belonging to a nation. To local patriots, tourism promised innovative avenues of commercial and industrial development and a wider coverage of local attractions. To the state, it offered the opportunity to recruit peripheral elites to the task of strengthening those subnational entities that were compatible with greater centralism. In order to understand how this happened, it is important to know that in the early part of the twentieth century several forms of centralism and regionalism coexisted or clashed in a spectacular way while the central government was still struggling to achieve national cohesion.

As Xosé Manoel Núñez Seixas points out, Spain's loss of its last colonies in 1898 brought to the forefront of public debate a whole array of peripheral selfidentifications. Apart from the better-known separatist ideologies propelled by some Catalan and Basque intellectuals, there were cultural movements in support of regional languages (in Galicia and Catalonia), peripheral nationalisms without claims for political self-determination (in Andalucía), and the fuerista currents seeking to restore the medieval map of "historical regions." Such variety presented a major obstacle to nationhood: it meant that in spite of the well-rooted local loyalties, or perhaps precisely because of them, there was still no social consensus about entities larger than a town from which to build the nation. Should these be historical kingdoms, or cultural regions, or linguistic communities? Prior to implementing any nation-building task, the Spanish state thus had to decide who to talk to and who to neutralize. In the 1910 s, the state began to bet on one such subnational entity: the province. Seeking ways to mobilize regionalist patriotisms but unwilling to cede political power, a succession of governments used these merely administrative entities as pieces of their nation-building puzzle. In 1913, provincial administrations even received a right of political quasi-autonomy when, according to the Law of Mancomunidades, they were allowed to sign their own subnational agreements and form associations with other provinces.

But how did the question of the cultural identities of Spain's provinces appear on the nation builders' agenda in the first place? Spain had been divided into provinces in 1833, following the French model of departments. Although that political map reflected the government's concern for erasing old kingdoms

${ }^{5}$ Xosé Manoel Núñez Seixas, "The Region as Essence of the Fatherland: Regionalist Variants of Spanish Nationalism (1840-1936)," European History Quarterly 31, no. 4 (2001): 483-518, 502; for a Valencian interpretation, see José Vila Sera, El regionalismo en España (Valencia, 1919). 
and distributing territory and the population into more or less equal units, its design was not initially questioned because it respected historical regions' borders (fig. 1). ${ }^{6}$ Provinces were modern entities that were mostly administrative or bureaucratic; they did not incite feelings of cultural identification in the ways that the patriotisms connected with old-regime kingdoms or municipal dwellings did. Even as late as in the 1920s, Spanish intellectuals were finding provincial loyalties weak if not nonexistent and proposed to do away with them. ${ }^{7}$ José Ortega y Gasset, at the time Spain's most influential thinker, claimed that the prime element with which to build the nation was not the province but rather what he called a "large municipal district" ( gran comarca) ${ }^{8}$ By then, however, the dictator Miguel Primo de Rivera (1923-30) had come to the conclusion that only provinces could be the constitutive entities of Spanish nationhood. Since these were devoid of any common cultural past and did not generate patriotic feelings, tourism was entrusted with the task of forging those feelings by crafting for each province its own unique markers.

Still, understanding the intricacies of regionalism in the context of centralization requires accepting that nation formation does not necessarily imply the weakening of peripheries. Since the publication of Celia Applegate's A Nation of Provincials: The German Idea of Heimat, which reconsidered regionalists' attitudes toward social and industrial modernization, historians' interest in localism and its relationship to centralism has been steadily on the rise. Stéphane Gerson

\footnotetext{
${ }^{6}$ Thus, each medieval kingdom was subdivided into several provinces clustered around its most important eponymous municipalities. Jean Louis Guereña finds one telling concession to the historical kingdoms: the county of Treviño, geographically situated in the province of Álava, was attached to the province of Burgos because it historically belonged to the Crown of Castile. Guereña attributed this exception to the aftermath of the first Carlist War. "État et nation en Espagne au XIXe siècle," in Les nationalismes en Espagne de l'État libéral à l'État des autonomies, ed. Francisco Campuzano Carvajal (Montpelier, 2001), 27.

${ }^{7}$ For a detailed overview of these debates, see Ferrán Archilés, "La novela y la nación en la literatura española de la restauración: Región y provincia en el imaginario nacional," in Provincia y nación: Los territorios del liberalismo, ed. Carlos Forcadell Álvarez and María Cruz Romeo Mateo (Zaragoza, 2006), 161-90; Francisco Campuzano Carvajal, ed., Les nationalismes en Espagne de l'État libéral à l'État des autonomies (Montpelier, 2001), esp. Jean Louis Guereña, "État et nation en Espagne au XIXe siècle," 17-38, and Xosé Manoel Núñez Seixas, "Provincia, región y nación en la España contemporánea: Una (re)interpretación global en perspectiva comparativa," and Juan José Carreras Ares, "Alternativas territoriales a los metarrelatos nacionales," in Provincia y nación: Los territorios del liberalismo, ed. Carlos Forcadell Álvarez and María Cruz Romeo Mateo, 297-312 and 313-20. For a comprehensive summary and analysis of turn-of-the-century regionalist debates, see Xosé Manoel Núñez Seixas, "The Region as Essence of the Fatherland," and "Unidad y diversidad de las naciones en España: Una visión panorámica," Cuadernos de alzate 39 (2008): 61-77.

${ }^{8}$ José Ortega y Gasset, "La unidad política local es la gran comarca," El Sol (Madrid), February 24, 1928, 1.
} 


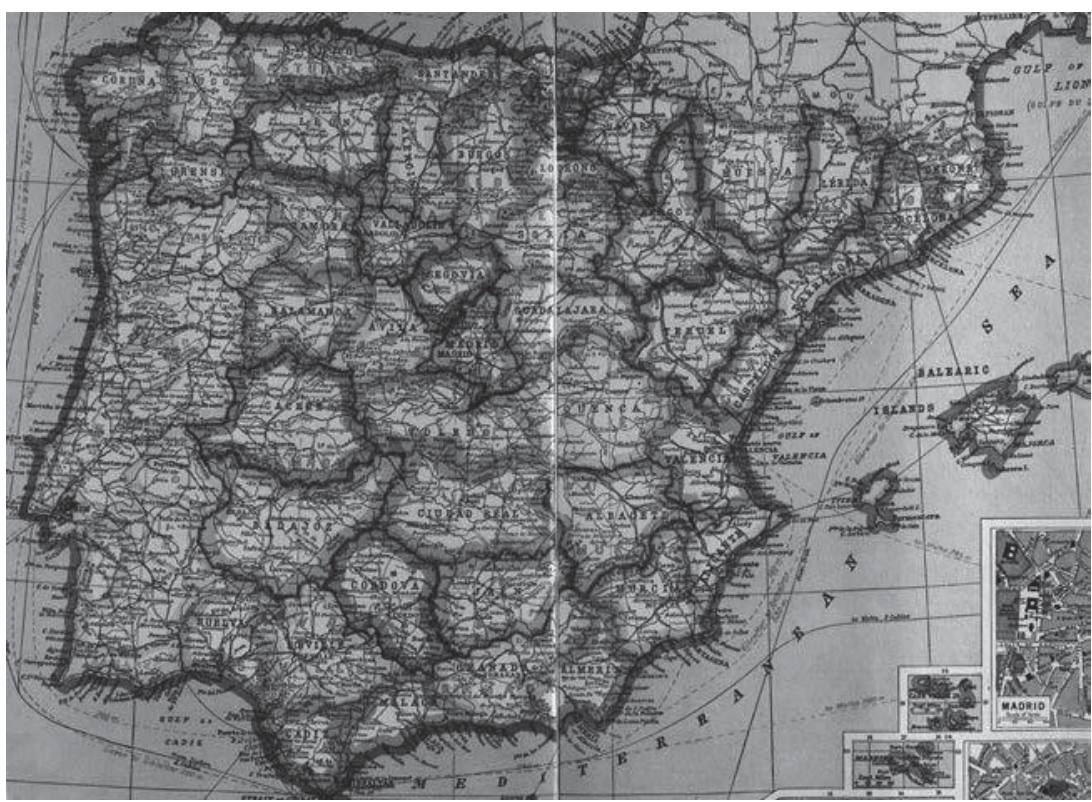

FIG. 1.-A map of Spain and Portugal, with provinces color coded. J. A. Hammerton, ed., Harmsworth's Atlas of the World and Pictorial Gazetteer (London, 1921, 132-33). From the American Geographical Society Library, University of Wisconsin-Milwaukee Libraries. A color version of this figure is available online.

has encountered similar ideas among the provincial intellectuals in nineteenthcentury France, demonstrating that the local was already part of the national under the July Monarchy and the Empire. ${ }^{9}$ Moving the debate even further, Eric Storm has recently proposed to denationalize regionalism by interpreting it as a transnational social and aesthetic movement of the elites, domestic or foreign, residing in the European capitals. ${ }^{10}$ One advantage of such an approach is that it describes regionalism as a self-contained ideology whose relationship to the political battles for peripheral self-determination or national integration was far from straightforward. As Storm argues, depending on the political contexts, regionalists could support or contest centralizing claims, or simply choose to ignore them. ${ }^{11}$

\footnotetext{
${ }^{9}$ Stéphane Gerson, The Pride of Place: Local Memories and Political Culture in Nineteenth-Century France (Ithaca, NY, 2003).

${ }^{10}$ Eric Storm, "Regionalism in History, 1890-1945: The Cultural Approach," European History Quarterly 33, no. 2 (2003): 251-65, and The Culture of Regionalism: Art, Architecture and International Exhibitions in France, Germany and Spain, 1890-1939 (Manchester, 2011).

${ }^{11}$ Storm, The Culture of Regionalism, 10-13.
} 
If regionalism was indeed transnational, then early tourism, a practice enjoyed concomitantly by the same social groups that were involved in region making, is also relevant for understanding that phenomenon. Storm initiated this inquiry by examining how some European governments appropriated vernacular architectures into the installations built for the early twentieth-century worlds' fairs. ${ }^{12}$ Such an approach to state tourism planning is, of course, consistent with its predominant image of a centralized power feeding on turn-of-the-century regional revivals. Yet it does not do justice to the full potential of Storm's own discovery or to other historians' views of region making as an inherent component of centralization. Looking at tourism as an officially sanctioned "afterlife" 13 of regionalist undertakings may lead us to imagine that regionalism was opposed to tourism acting in the service of the state, which was only concerned with integration. However, it has not always been this way.

Once we discern the uncertainties about the forms and directions of government intervention in early tourism policies, state-run hospitality starts to look less like a coherent top-down program and more like an intellectual quest for ways to unify nations by engaging their peripheral patriotisms. This quest went in two directions. On the one hand, governments were concerned with promoting local and regional loyalties just as much as the national ones. On the other hand, regionalists needed tourism as well — mainly because tourism consumption could invigorate their markets. Thus the crafting of vernacular cultures by regionalists was made possible not just by the greater mobility of people, objects, and ideas; it was also aided by the states' attempts to harness that mobility in ways that would spur visitors' interest toward national monuments and landscapes. Local entrepreneurs, of course, promoted excursions, hotels, monument protection, commercial entertainment, and railroads long before these became state priorities. But they very soon realized that some form of interaction with the state was necessary to the success of their activities. Spain's local developers were as disjointed as its local patriots, and this is why a government structure was created early on to coordinate their efforts, making Spain the flagship of state-run tourism.

Why could tourism so efficiently connect regionalism and centralism? Anthropologists and historians who have studied the interdependence of tourism and localism offer some insight. One explanation comes from Michel Picard's anthropological model of regional identities as products and practices of what he calls "touristification." Considering tourism as a mediating force between political region making and locality-based cultural patriotisms, Picard defines "touristification" as the process whereby politically delineated territories become legitimized as culturally bound communities through consumption by strangers. It is

${ }^{12}$ Ibid., 145-296.

${ }^{13}$ Ibid., 195. 
important to note that Picard's approach views tourism not as a mere branding technique but rather as a productive technology that operated "by blurring the boundaries between the inside and the outside, between what is 'ours' and what is 'theirs,' between that which belongs to 'culture' and that which pertains to 'tourism." "'14 This perspective leads the author to observe that what people perceive as regional "culture" is actually constructed from a heterogeneous array of religious customs, crafts, building styles, and everyday habits of local people. Prior to "touristification," regional cultures are neither classified as cultural nor tied to a region - an entity whose origins are always political or administrative. Thus, in the era of mass mobility, governments need tourism to naturalize regions by producing cultures that can fit well with territorial integration.

As we will see, similar processes were at work in the development of place identities in Spain. At different times these "touristified" cultures were referred to as regional or provincial, but even when they were considered regional they were not incompatible with the task of creating national cohesion. Among the building blocks from which tourism enthusiasts crafted these cultures, a particularly important role was reserved for domestic cooking. In the early twentieth century, local recipes and ingredients received new life thanks to travel and tourism propaganda. As Julia Csergo demonstrates, just as the modern food industry was beginning to develop, the state became eager to support the ideologies of food cooked from supposedly irreplaceable local ingredients. ${ }^{15}$ These, of course, were just as useful for developing regional allegiances as they were for distinguishing certain areas from the center and making people travel to appreciate them. In Stephen L. Harp's apt wording, at the end of the nineteenth century, "while the centralized French political state avoided any devolution of political power to the regions, French cultural discourse provided a place for the regions, albeit one in which differences were lined up, homogenized, and packaged for Parisians, other French, and even foreigners to experience." ${ }^{\prime 16}$ Priscilla Parkhurst Ferguson points out that the resulting culinary map of France's regional cuisines was consistent with the Third Republic's program of promoting the "pedagogy of national distinctiveness through complementary difference." ${ }^{.17}$ Local soils and the unique products that these could support transformed the abstraction of "complementary

${ }^{14}$ Michel Picard, "Cultural Tourism, Nation-Building, and Regional Culture: The Making of a Balinese Identity," in Tourism, Ethnicity, and the State in Asian and Pacific Societies, ed. M. Picard and Robert E. Wood (Honolulu, 1997), 183.

${ }^{15}$ Julia Csergo, "La constitution de la spécialité gastronomique comme objet patrimonial en France: Fin XVIIIe-XXe siècles," in L'esprit des lieux: Le patrimoine et la cité, ed. Daniel J. Grange and Dominique Poulot (Grenoble, 1997), 183-93.

${ }^{16}$ Stephen L. Harp, Marketing Michelin: Advertising and Cultural Identity in TwentiethCentury France (Baltimore, 2001), 237.

${ }^{17}$ Priscilla Parkhurst Ferguson, Accounting for Taste: The Triumph of French Cuisine (Chicago, 2004), 127. 
difference" into something that one could taste. This is how, as Amy B. Trubek reminds us, the ideology of terroir was born. ${ }^{18}$

While learning from their neighbors how to design and use the tools of cultural nation building, Spanish elites came up with their own version of complementary difference, which they called "diversity," Lara Anderson explains. ${ }^{19}$ At the time when Spanish women writers were publishing extensively on regional cooking, ${ }^{20}$ this ideology of culinary diversity emerged as a male project that ignored female contributions. Adding to this expanding discussion on gastronomy and modernization in Spain, my article will demonstrate that, unlike French cultural regionalists, Spanish intellectuals discovered early on that their diversified nation would look more convincing if the state did not leave it to private businesses to decide which regions to promote and how to do it. Spain's layered and heterogeneous parts did not fit well together on the political map, and some of them threatened to break away. Could a map of tourist routes, cultural markers, and regional food gloss over these contradictions? Spain's first tourism officials were determined to find it out.

\section{Krausismo, Nation Building, and the Origins of State-Run Tourism}

Sasha D. Pack traces the ideological roots of tourism in Spain to the patriotic program of national revival known as Regenerationism (regeneracionismo) ${ }^{21}$ In 1898, when Spain lost its last colonies to the United States, the regeneracionista writers, statesmen, and scientists began to claim that a new nation would emerge from the rural areas rather than the cities. This suggests, as a useful starting point, that the connection between the political, economic, and cultural identities of Spanish rural regions that resulted from state tourism policy also relied on the ideology of Regenerationism. That was, however, a blanket term for diverging political, economic, and scientific positions that had in common only their

${ }^{18}$ Amy B. Trubek, The Taste of Place: A Cultural Journey into Terroir (Berkeley, 2008).

${ }^{19}$ Lara Anderson, Cooking up the Nation: Spanish Culinary Texts and Culinary Nationalization in the Late Nineteenth and Early Twentieth Century (Woolbridge, 2013), 15-16.

${ }^{20}$ María del Carmen Simón Palmer, Bibliografia de la gastronomía española: Notas para su realización (Madrid, 1977), and the particularly useful Rebecca Ingram, "Spain on the Table: Cookbooks, Women, and Modernization, 1905-1933" (PhD diss., Duke University, 2009).

${ }^{21}$ Sasha D. Pack, "Tourism, Modernization, and Difference: A Twentieth-Century Spanish Paradigm,” Sport in Society 11, no. 6 (2008): 657-72. The origins of Regenerationism are credited to the writer, agronomist, and politician Joaquín Costa. For a comprehensive summary see Joseph Harrison, "Tackling National Decadence: Economic Regenerationism in Spain after the Colonial Debacle," in Spain's 1898 Crisis: Regenerationism, Modernism, Post-Colonialism, ed. Alan Hoyle (Manchester, 2000), 55-67. 
dedication to nation building and their interest in the rural periphery. The regeneracionistas differed greatly in their opinions about the role that regions would have to play in a modern nation. ${ }^{22}$ But the nation-building agendas of Spain's early tourism enthusiasts appear more coherent if we step further back in time to examine their intellectual foundations: the nineteenth-century philosophical and political current known as Krausismo.

It is remarkable that in Spain the ideology of tourism - a classic transnational activity - had its origins in this nineteenth-century school that was also radically trans-European. The influence of the German pantheist philosopher Karl Christian Friedrich Krause (1781-1832) on the thinking of several generations of Spaniards grew out of the work of one man: Julián Sanz del Río (1814-69). Dispatched by Spain's government to Germany in 1843, Sanz del Río made a stop in Brussels to meet the legal philosopher Heinrich Ahrens (1808-74), who had been Krause's disciple. ${ }^{23}$ Following Ahrens's advice, he dedicated his subsequent stay in Heidelberg to studying Krause's work (and turning a deaf ear to "the songs of other philosophical sirens" such as Hegel, Sanz del Río's critic Marcelino Menéndez y Pelayo would later say ${ }^{24}$ ). Upon his return, Sanz del Río translated Krause's books and developed his teachings so successfully that his interpretations laid the groundwork for a new school of thought.

The Krausistas were practical people who channeled their ideas through parliamentary politics and education, becoming particularly influential after the 1868 revolution that struck the final blow against the old regime. In 1876, Sanz del Rio's disciple Francisco Giner de los Ríos (1839-1915) founded the Institución Libre de Enseñanza, a private school that propelled a reform of Spain's public education. Historians usually refer to Giner de los Ríos and his circle of colleagues, disciples, and friends as Krausoinstitucionistas or Krausopositivistas to account for the coherence of their philosophical and political projects and their shared interest in positivism. ${ }^{25}$ Social reform was one area where they were

${ }^{22}$ Núñez Seixas calls it "the regionalist ambiguity of Regenerationism" ("The Region as Essence of the Fatherland," 499).

${ }^{23}$ Juan López-Morillas, The Krausist Movement and Ideological Change in Spain, 1854-1874, trans. Frances M. López Morillas (Cambridge, 2010), 7. For an updated history, see Enrique M. Ureña, "Krause y los Krausistas alemanes y españoles," in $L a$ Institución Libre de Enseñanza y Francisco Giner de los Ríos: Nuevas perspectivas, vol. 2, La Institución Libre de Enseñanza y la cultura española, ed. José Garcia Velazco and Antonio Morales Moya (Madrid, 2012), 236-59.

${ }^{24}$ Historia de los heterodoxos españoles (Madrid, 1880) (electronic resource: Menéndez Pelayo digital: Obras completas, epistolario y bibliografia [Madrid: Fundación Ignacio Larramendi: Fundación MAPFRE, 2009]), 6:371-72.

${ }^{25}$ For the terms Krausoinstitucionismo and Krausopositivismo, see Juan Ramón García Cue, Aproximación al estudio del Krausismo andaluz (Madrid, 1985). See also Manuel Suárez Cortina, "El proyecto sociopolítico del republicanismo español," in Movimientos 
particularly influential. Following the example of British late-Victorian reformers, their programs sought social harmony through an improvement of living conditions and schooling for the laboring classes. Educational excursions and the teaching of aesthetics were the cornerstones of their school reform, and this meant that the Krausoinstitucionista presence would become particularly widespread in turn-of-the-century organized travel and in the art world. ${ }^{26}$

Giner de los Ríos and his followers focused mostly on nationhood: they considered nation formation the central process of their epoch and defined it as the transitional stage between disjointed kingdoms and multinational states. Their approach was rooted in evolutionary ideas that caused them to view national unity as a long chain of "organic integration" and "growing assimilation." ${ }^{27}$ This was not, however, Darwin's evolutionism: the Krausistas borrowed heavily from the Romantic philosophy of nature and Haeckel's monism. ${ }^{28}$ Their hybrid system of beliefs viewed all objects in both natural and social realms, as well as the categories that humans produced to understand them, as results of an ongoing two-stage development. From the starting point of a single homogenous object, the needs of evolutionary adaptation (as the first Krausistas imagined it) triggered

sociales en la España del siglo XX, ed. María Dolores de la Calle and Manuel Redero San Román (Salamanca, 2008), 17-44.

${ }^{26}$ For more information about the history of the Krausismo and Krausoinstitucionismo, see, among others, Joaquín Xirau, Manuel Bartolomé Cossío y la educación en España, 2d ed. (Barcelona, 1969); Juan López Morillas, Krausismo: Estética y literatura (Barcelona, 1973); Antonio Jiménez-Landi, La Institución Libre de Enseñanza y su ambiente (Barcelona, 1996); and Javier Moreno Luzón, "Los institucionistas, el Partido Liberal, y la regeneración de España," in La Institución Libre de Enseñanza y Francisco Giner de los Ríos: Nuevas perspectivas, vol. 1, Reformismo liberal: La Institución Libre de Enseñanza y la política española, ed. Javier Moreno Luzón and Fernando Martínez López (Madrid, 2012), 142-79.

${ }^{27}$ Manuel Suárez Cortina, "El Krausismo, la República y la 'España regional' en el siglo XIX," in Federalismo y cuestión federal en España, ed. Manuel Chust (Castellón, 2004), 162-98, 183.

${ }^{28}$ Evolution of the Species appeared in Spain late and in a much modified form. The first editions were Barcelona, 1876, and Madrid, 1877. See Thomas F. Glick, Darwin en España (Barcelona, 1982); Thomas F. Glick, Miguel Ángel Puig-Samper, and Rosaura Ruiz, The Reception of Darwinism in the Iberian World: Spain, Spanish America, and Brazil (Dordrecht, 2001); Diego Núñez Ruiz, La mentalidad positiva en España: Desarrollo y crisis (Madrid, 1975); Francisco Pelayo López, "Darwin en España: Las controversias sobre la teoría de la evolución en la comunidad científica española," Apuntes de ciencia y tecnología 33 (2009): 27-33; Francisco Blázquez Paniagua, "Notas sobre el debate evolucionista en España (1900-1936)" (undated, http://www.biblioteca.org.ar /libros/200565.pdf) and "Breve historia del darwinismo en España," Ambiociencias (December 2009): 23-29 (http://www.febiotec.es/files/ez/docs/proyectodebe.pdf); Julio Simó Ruescas, "La Naturphilosophie en España: La recepción del evolucionismo en el entorno de la tradición Krausista, Asclepio 56, no. 2 (2004): 197-222 (http://asclepio .revistas.csic.es/index.php/asclepio/article/viewArticle/44). 
within that object a process of "inductive" (or "analytical") internal diversification of parts. With time, parts would specialize, develop further, and enter into the second "deductive" or "synthetic" phase of integration into one body that was no longer homogenous but rather internally diversified, sometimes to the point of integrating opposite extremes. Both phases were then infinitely repeated in all ensuing agglomerations.

The Krausista "evolution" was therefore a process of internal differentiation producing centrifugal and centripetal forces; the antagonism between these forces was presented not as destructive but rather as the source of further associations of organs and bodies. Although the details varied, Giner and his disciples liked to uncover this law in all phenomena, ranging from microorganisms to state institutions to national cultures. In this schematic, any variety or unity was also a phase in an ongoing process involving some underlying commonality and creating more and more heterogeneous agglomerations with more and more specialized parts. ${ }^{29}$

In the debates on nation formation, these views translated into projects involving increasing individualization as well as integration, beginning with families (united free individuals) and moving on to municipalities, regions, nations, and, as Krause envisioned in 1814, coalitions of "organic" multinational states. ${ }^{30}$ Crucially, for Krausistas each developmental stage was integrated into larger subsequent bodies, and although on the surface these previous phases manifested themselves as antagonistic to one another, it was precisely their apparent incompatibilities that created the preconditions for future wider agglomerations. Equally important, Krausistas viewed the national state itself as a temporary substitute for other structures of social life that would integrate prenational stages in a harmonious way. They were also keen on distinguishing elements of subnational lifestyles that would demand partnership with other subnational entities in order to be fully realized.

According to this thread of social evolutionism, the diversity of regional arts and crafts significantly increased the nation's potential for unification, as more specialized cultural forms would produce more and more individualized regions that would need more and more robust connections. The historical contribution of these members of the elite to nation building thus included teaching the common people in Spain's localities to appreciate their own lifestyles by reconfiguring them as regional "cultures." These ideas explain why Krausoinstitucionistas, the graduates of the Institución Libre de Enseñanza influenced by positivism, de-

\footnotetext{
${ }^{29}$ See specific discussion about this interpretation of Krause's epistemology by Julián Sanz del Río in Adolfo Posada, Breve historia del Krausismo español (Oviedo, 1981), 40.

${ }^{30}$ See Francisco Querol Fernández, "El sueño europeo: El proyecto Krauseano de una federación de estados" (appendix), in La filosofía del derecho de K. Ch. F. Krause (Comillas, 2001), 449-70.
} 
voted so much attention to identifying different forms of local and regional selfexpression, ranging from peripheral law codes ( fueros) to crafts and customs. For example, Krausoinstitucionistas became the first collectors of regional pottery and embroidery, the first scholars to classify vernacular architectures, and the earliest supporters of writing down and keeping recipes of local, home-cooked specialties, as the last section of this article will describe. ${ }^{31}$

Still, although nation building and regional revival were common concerns among the statesmen and thinkers normally included in this milieu, there was no clear agreement on what they meant by "region" or what role they reserved for the nations' capitals and state institutions. Nor was it clear whether "organic agglomerations" needed a center at all, although the politicians of the Krausoinstitucionista generation recognized a provisional need for a structure identified as the state. ${ }^{32}$ In the discussions of a "regional Spain" that took place in the $1860 \mathrm{~s}-80$ s, Republican federalists, for example, welcomed the Krausista faith in historical systems of law, while liberal centralists found the notion of strong nationhood useful. ${ }^{33}$ At the same time, Krausista social philosophers were indifferent to the debate between specific types of subnational entities, since each was supposed to be a mere phase in the chain of ongoing human integration. In other words, they did not care whether the agglomerations larger than municipalities that were to become parts of the Spanish nation were historical kingdoms (perceived as culture-rich) or modern provinces (perceived as merely administrative and thus culture-poor). Suárez Cortina cites an 1885 passage from Eduardo Pérez Pujol: "Today, Nation is the total human society incarnated by the State. But inside national territory and without breaking the unity of a Nation's spirit—-but rather strengthening it and enriching with the variety of organisms that contribute to

${ }^{31}$ Sofía Rodríguez Bernis, "Las artes populares en la ILE," in La Institución Libre de Enseñanza y Francisco Giner de los Ríos: Nuevas perspectivas, vol. 2, La Institución Libre de Enseñanza y la cultura española, ed. José García Velazco and Antonio Morales Moya (Madrid, 2012), 800-815.

${ }^{32}$ Salmerón's 1872 revolutionary "Organic Federated Republic" was imagined as a decentered nation of cantons that were, in turn, associations of municipalities, while Salmerón and Chao's 1891 speech defended "region" as the primary unit of nationhood. See Nicolás Salmerón y Alonso and Eduardo Chao, Proyecto de bases de la Constitución Republicano-Federal de España, 2, quoted in Antonio Heredia Soriano, "El Krausismo español y la cuestión nacional," Enrahonar: Quaderns de filosofía 16 (1990): 105-22, 116; Salmerón, "Discurso en el Teatro del Círculo Ecuestre de Barcelona (7.1.1891)," quoted in Heredia Soriano, "El Krausismo español," 114. See also Suárez Cortina, "El Krausismo, la República y la 'España regional' en el siglo XIX," 188.

${ }^{33}$ But the Krausoinstitucionista regionalism was also a project where time was as influential and important as any government decision, because this ideology required a bottom-up transformation of lifestyles. See Elias Díaz, La filosofía social del Krausismo español (Valencia, 1983), 20-25, and Heredia Soriano, "El Krausismo español y la cuestión nacional." 
forming it $—$ one finds regions . . . and under these, the municipal units that are better defined by their very nature, divided into urban and rural." ${ }^{\prime 34}$

Pérez Pujol used "region" and "province" interchangeably, stating that "according to each country's nomenclature" they could be called "provincias, counties, departements, amter, lands, or goubernia." Krausista reformers made no distinction between regions and provinces, as both were viewed as associations of "natural" municipalities. Thus the evolutionist approach adopted by these thinkers undercut Spain's most lasting debate: the competition among regions, provinces, and municipal areas about which of them was more natural or legitimate. When this circle of ideas met tourism policy, the Krausista reformers thought they had found a new avenue for achieving their vision of Spain through the crafting of cultures, both national and subnational.

But Krausistas invented neither the tourism business nor organized travel in Spain. The country's first tourism activity was the work of municipal authorities, local investors (hotel owners, people with an interest in railroads, etc.), comités de festejos in charge of patron saint festivals, and chambers of industry and commerce. All of these groups were seeking to make their municipalities known by improving transport and accommodation and developing an attractive mix of high-culture attractions, local celebrations (which at that time were already highly commercialized), and the network of urban consumption. Their strategies normally copied the model of the French tourist syndicates. Hence, by the time the government jumped onto the tourism bandwagon, tourist development associations already existed in several Spanish localities. The first ones had appeared in San Sebastián in 1903 and in Mallorca in 1905. After the state created its own structure, independent entities continued to emerge at a similar pace. ${ }^{35}$

Likewise, long before the state got interested in tourism, Spaniards were founding touring societies. These associations organized short-term group trips called excursiones on the model of the travel for sporting purposes (alpinism, cycling, and, later, automobile touring) that had been developed in France and other countries. They also disseminated information and published the notes of their travelers. ${ }^{36}$ However, the first excursionist association in Spain, formed in 1876 in Catalonia, sought to reconstruct this historical region by promoting

${ }^{34}$ Eduardo Pérez Pujol, "Prólogo al curso de derecho administrativo según los principios y la legislación actual de España, por Vicente Santamaría de Paredes" (Madrid, 1885), quoted in Suárez Cortina, "El Krausismo, la República y la 'España regional' en el siglo XIX," 185.

${ }^{35}$ In Barcelona and Zaragoza in 1908, in Madrid, Cádiz, and Tarragona in 1910, in Murcia in 1911, in Burgos and Valencia in 1912, and so on. See Ana Moreno Garrido, Historia del turismo en España en el siglo XX (Madrid, 2007), 55-56; María Rosa Cal Martínez, "La propaganda del turismo en España: Primeras organizaciones," Historia y comunicación social 2 (1997): 125-33.

${ }^{36}$ Moreno Garrido, Historia del turismo en España, 37. 
geographical knowledge that confirmed Catalonia's natural borders and unique landscape.$^{37}$ These were sport activities of a separatist kind, and none of them was a Krausista invention.

The Krausista-inspired tourism tradition began when Giner de los Ríos adapted Catalan excursionist practices for his own sociophilosophic quest. As a thinker rooted in Krause's pantheism, Giner maintained that it was possible for people to understand God's design for creation by contemplating and analyzing nature. As a self-professed admirer of the Romantics, he had a soft spot for mountainous regions. As a social reformer, he sought ways to encourage people to leave hygiene-challenged cities and take a breath of fresh country air. Catalan excursionism was the closest to what he had in mind, and the Guadarrama elevation was the mountainous region that was nearest to Madrid. In 1886 Giner founded the Society for the Study of Guadarrama (Sociedad de estudios de Guadarrama), ${ }^{38}$ establishing the model for Krausoinsticionista excursionism. ${ }^{39}$ Reflecting its growing popularity, in 1893 a group of aristocrats and intellectuals from Madrid founded the Spanish Excursionist Society (Sociedad española de excursiones).$^{40}$ Its statutes announced as its prime objective the study of "Spain considered in all its aspects and especially in scientific, historical, artistic, and literary ones." These formulations left no place for peripheral nationalism or sport. This society, whose membership included enthusiasts of protecting local historical and artistic monuments, became an authority in all matters pertaining to the classification and description of Spain's heritage. In particular, its Boletin (published beginning in 1893) set the standard for writing about the architectural landmarks of various places in Spain from the perspective of educated aficionados residing in Madrid. The tradition created in this publication channeled Krausoinstitucionista-inspired views into early tourism policy.

Those ideas, however, had no official influence in the first government body, the National Commission for the Development of Artistic and Leisure Excursions of the Foreign Public, which was created in 1905. That first agency responsible for tourism simply modeled itself on private business and acted as an investor

${ }^{37}$ Joan Nogué, "Nacionalismo, territorio y paisaje en Cataluña," in Paisaje, memoria histórica e identidad nacional, ed. Nicolás Ortega Cantero (Madrid, 2005), 147-70. Associació catalanista d'excursions científiques was created in 1876 and the Associació d'excursions catalana was formed in 1878; in 1891 the two associations merged to create the Centre excursionista de Catalunya.

${ }^{38}$ Francisco Giner de los Ríos, "El paisaje. II," La ilustración artística 220 (1886): $103-4,103$.

${ }^{39}$ For more on the Krausoinstitucionista excursionism, see Nicolás Ortega Cantero, Paisaje y excursiones: Francisco Giner, la Institución Libre de Enseñanza y la Sierra de Guadarrama (Madrid, 2001), and Ortega Cantero, Paisaje, memoria histórica e identidad nacional.

${ }^{40}$ The multiple excursionista societies emerging in different cities at that time used the "sport" and the institucionista approaches in different proportions. 
where business did not show enough energy. It was created through the efforts of a group of liberal and conservative deputies led by the Minister of Development. ${ }^{41}$ Although available sources do not specify who, apart from the minister himself, actually worked in the commission, we know who was invited to work: the president of the Catalan Excursionist Society, the publisher of the Gaceta de los caminos de hierro, the directors of four railroad companies, and the philologist and historian Marcelino Menéndez y Pelayo, who was a notorious critic and antagonist of the Krausistas. ${ }^{42}$ The 1905-11 commission was thus an honest attempt to mediate between different business interests without pressing any political agenda onto local developers. Showing no explicit interest in regional identity making, it was mainly charged with creating itineraries around Spain and advertising them abroad, negotiating special packages with railroad owners, mobilizing administrative bodies for improving lodging, and ensuring that Spain's artistic and natural attractions were appropriately described and advertised in foreign languages. ${ }^{43}$

Hence, although by the beginning of the century organized travel in Spain for Spaniards was already a Krausista domain, the state's earliest tourism policy was only concerned with efficiency and information and did not deal in identity making. What happened, however, was that the 1905 commission, charged merely with advertising monuments, soon assumed a role in their protection, study, and description.$^{44}$ Krausista thinking influenced all three of these activities, and its influence carried over into the practices of the Spanish Excursionist Society. In 1911, when the commission was replaced by the Royal Commissariat, the Krausoinstitucionista influence became institutionalized and a special form of tourism-driven regionalism was born.

\section{KRAUSISTA Tourism and Social Regionalism}

The Royal Commissariat for Tourism and Popular Artistic Culture, created in 1911, shifted the balance between regional entrepreneurs and the state, making state-run tourism a more completely Krausista venture. The Royal Commissar, Benigno de la Vega-Inclán (II Marquis de la Vega-Inclán, 1858-1942), was a personal friend of Giner and some of his disciples, particularly Manuel Bartolomé Cossío (1857-1935), with whom he collaborated on the creation of the El Greco Museum and other artistic undertakings. In addition to being a museum enthusiast, he was a visionary whose ideas would prove far-reaching enough to inspire

${ }^{41}$ Pack, "Tourism, Modernization, and Difference."

${ }^{42}$ As reported in "Fomento del turismo," Gaceta de los caminos de hierro, October 24, $1905,476$.

${ }^{43}$ Real Decreto, October 6, 1905.

${ }^{44}$ María Rosa Cal Martínez and Beatriz Correyero Ruiz, Turismo, la mayor propaganda de Estado (Madrid, 2008), 68. 
Spain's tourism boom in the 1960s. As the head of the Royal Commissariat, Vega-Inclán applied Krausista views on nature, art, and society to the design of travel destinations that he called "environments." His new government structure put Spain forward as an "open-air museum" and made the protection of monuments a state priority. ${ }^{45}$

The commissariat was the first to officially proclaim tourism as a vehicle of national revival and to refuse to distinguish between its international and domestic, regional and national functions. As suggested in its long official title, for the Royal Commissariat tourism meant education as well as community building. Its foundational decree charged the organization with "proposing measures leading to popularizing elementary knowledge of art and raising collective artistic culture." ${ }^{\prime 46}$ Only its third mandate mentioned anything international, and even then the need for promoting "international relations" was limited to "artistic matters. ${ }^{~}{ }^{47}$ The questions of transport and lodging were relegated to the fourth place. When the commissariat received a budget, it came from the Ministry of Public Instruction and Fine Arts and not from the Ministry of Development (Ministerio de Fomento), as would have been logical for a revenue-producing activity.

Having established art education as a priority, Vega-Inclán launched a series of publications about Spain called "Libraries of Art" that promoted the Krausista agenda of aesthetics as the foundation for public instruction. ${ }^{48}$ These ranged from short monographs about individual artists and museums to guidebooks for cities, regions, and Spain as a whole. Whatever the topic, such texts were written by Spanish art critics, historians, architects, and archeologists. ${ }^{49}$ When local en-

${ }^{45}$ The policies and measures of the Royal Commissariat are described in detail in Cal Martínez, "La propaganda del turismo en España"; Cal Martínez and Correyero Ruiz, Turismo, la mayor propaganda de Estado, 73-119; Juan Carlos González Morales, "Turismo en España (1905-1931)" (PhD diss., Universidad Carlos III, 2003); and Moreno Garrido, Historia del turismo en España.

${ }^{46}$ Real Decreto, June 19, 1911.

${ }^{47}$ Besides, Article 5 made it clear that the Royal Commissariat was above all interested in foreigners coming from the Americas, many of whom were either Spaniards or their close descendants.

48 "Bibliotecas del arte."Article 2 of the commissariat's budget contemplated "acquisition of copies of Libraries of Art to distribute them in schools, workshops, and all kinds of Centers and Societies. Posters and photos to be put by the stations, offices, and agencies of foreign and Spanish railroads. Funding for newspapers, pamphlets about regions, cities, and our most picturesque sites, costume, customs, and typical celebrations . . (24.999,96 per year)" (AGA Grupo de Fondos 5, Fondo 1.04/1.07, Caja 31/7396).

${ }_{49}$ Their names are mentioned in Vega-Inclán's request to the San Fernando Academy to review an unsolicited guidebook on Játiva by Buenaventura Pascual: "Srs. Cossío, Mélida, Cantón, Vegue, Doménech, Lampérez, Gómez Moreno, and other renowned authorities who collaborate in the work of propaganda and popularization of artistic, monumental, and picturesque Spain that this commissariat is undertaking" (August 7, 1921, AGA Grupo de Fondos 5, Fondo 1.04/1.07, Caja 31/7396). 
thusiasts volunteered their own texts, these were subjected to a vetting process through the San Fernando Royal Academy of Fine Arts. This happened, for example, with the Guidebook to the City of Játiva by Buenaventura Pascual, a schoolteacher from Benimaclet (Valencia) who had to wait for two years before his unsolicited publication was approved on behalf of the Academia, and even then it was approved at Vega-Inclán's request. When the report came, it praised the author's knowledge of art, the "universal language in which monuments convey their beauty and their history to their own people and to strangers. ${ }^{150}$ Conversely, the reviewer criticized the author for including in the guidebook too much information about factories and other industrial buildings.

In contrast to the earlier national commission, which had sought to propagate the knowledge of Spanish monuments abroad, the 1911 commissariat understood "art education" as the education specifically of domestic laboring classes. This is why, according to a 1916 memorandum, Vega-Inclán considered his most successful operation to have been the distribution of 26,000 books about Spain's art and "popular culture" among a hundred workers' and educational centers. ${ }^{51}$ This second peculiarity of official tourism planning in the 1910s was related to a third one: the majority of the commissariat's actions disregarded any need for the development of tourist attractions or even the construction of hotels. Rather, the commissariat chose to dictate general measures concerning urban hygiene and the life of the working classes. Its policy, in other words, was not so much about foreigners as it was about their disenfranchised hosts, whose behavior seemed to demand government intervention. For example, in 1912 Vega-Inclán issued a proposal addressing the need to repress begging and improve the costumes of the people seen in railroad stations, while insisting that limitations be imposed on commercial advertising near historical monuments. The proposal stated that local people ought not to "be begging, showing off and exaggerating the exhibit of their rags and misery as professional bait-catchers." Instead, locals were encouraged to show "cleanliness, the object of poor-man's pride, selling fruits and products of their region in order to earn their living, dignifying themselves, and even providing services to travelers." ${ }^{, 52}$ The same proposal insisted that municipal administrations arrange for better trash removal, which

${ }^{50}$ Report by José Ramón Mélida, January (?) 10, 1923 (AGA Grupo de Fondos 5, Fondo 1.04/1.07, Caja 31/7396).

51 "The distribution that the Prince of Asturias patronized following H.M.'s initiative so that 4,000 boys and girls from the most needy and popular classes of Madrid could receive, before the end of the year, this illustrated souvenir and get an idea of Spain's monumental and picturesque beauty" (Madrid, January 18, 1916, El Comisario Regio Benito de la Vega Inclán al Excmo. Sr. Ministro de la Instrucción Pública y Bellas Artes, AGA Grupo de Fondos 5, Fondo 1.04/1.07, Caja 31/7396).

${ }_{52}$ August 4, 1912, "Noticia de algunas instancias elevadas por el Comisario Real del Turismo al Gobierno de Su Majestad de 1912 a 1917" (Madrid 1918), 9-10 (AGA Grupo de Fondos 5, Fondo 1.04/1.07, Caja 31/7396). 
would lead to greater urban hygiene. ${ }^{53}$ As for advertising, the Royal Commissar decreed that municipal governments must demonstrate more zeal in removing all commercial propaganda "incompatible with a monument and with the natural beauty of the landscape." ${ }^{.54}$

Such measures were consistent with the agenda of using state power to strengthen laboring-class local communities, but they were far from what investors expected from tourism; hence, unsurprisingly, these policies would eventually lead to clashes with tourism promoters in the regions, who claimed that the commissariat did not meet their needs. Already the 1912 proposal quoted above referred to some municipal administrators' "negligence and indifference bordering on hostility" and stated that appeals had been filed with higher authorities such as the Ministry of Public Instruction and the Higher Council for Excavations and Antiquities. ${ }^{55}$ Local entrepreneurs also claimed that the commissariat did not support regional development. In 1922, Jacinto Montllor, a member of the Barcelona Sociedad de atracción de forasteros, submitted proposals to the Ministry of Development and to the king that aimed at improving the distribution of the government's aid. ${ }^{56}$ When General Primo de Rivera staged a successful coup and established a dictatorship in support of King Alfonso XIII's monarchy, the opposition to the commissariat intensified, and proposals for creating a publicprivate alternative became more articulate. ${ }^{57}$ One of them would eventually terminate the existence of the Royal Commissariat and Vega-Inclán's involvement in tourism policy making.

When accused of not acting in the regions, Vega-Inclán defended himself by arguing that the municipal and provincial governments failed to contribute money or even a positive attitude..$^{58}$ Rosa Cal Martínez and Beatriz Correyero Ruiz make it clear that there were, in fact, no incentives for regional authorities built into the system. ${ }^{59}$ Indeed, Vega-Inclán's regionalism was of a peculiar kind. It reflected the Krausista theory that the elites based in Madrid could work directly with the provincial lower classes to develop regional cultures, completely bypassing local authorities, who were considered narrow-minded and corrupt. This program treated peasant lifestyles as essential ingredients for producing cultures and

${ }^{53}$ Ibid., 10.

${ }^{54}$ Ibid., 10. A year later, on June 23, 1913, another proposal reiterated the need of limiting "the advertisement and posters that, in the rural areas and by the monuments, disrupt [perturban] our artistic and monumental Spain" (ibid., 15).

${ }^{55}$ Ibid., 15.

${ }^{56}$ Ibid., 2-7.

${ }^{57}$ Cal Martínez and Correyero Ruiz (Turismo, 119-30) list several alternatives that were drafted after 1923.

58 "Contestación de la Comisaría Regia del Turismo a una instancia dirigida al Gobierno de Su Majestad" (Madrid, 1922), 2 (AGA Grupo de Fondos 5, Fondo 1.04/1.07, Caja 31/7396).

${ }^{59}$ Cal Martínez and Correyero Ruiz, Turismo, 79-80. 
attractions that would be able to offer an alternative to commercial entertainment. This is why the Royal Commissar privileged the least commercially promising elements of rural cultures instead of promoting money-making attractions that were of interest to local developers.

One of Vega-Inclán's favorite projects was the construction of an inexpensive housing neighborhood in Seville "with its own schools, gardens, and orchards." At the time, "garden cities" and affordable neighborhoods were trademark regionalist sites of the transnational kind that Storm has described ${ }^{61}$ From this point of view, the activity of the Royal Commissariat was well in line with the European projects of building villages and workers' colonies, administered from national centers but using local materials and local labor, that had been triggered by the reconstruction after World War I. But while other European nations were at war, Spain remained a neutral onlooker that experienced the conflict as an opportunity to accumulate capital and further its industrial modernization. Hence its projects, aimed at revitalizing peripheral economies as well as improving the living conditions of the laboring classes, sought to palliate the social consequences of quick industrial development. Vega Inclán's tourism policy responded to this need.

Nonetheless, for a Krausista-inspired Regenerationist such as Vega Inclán, the interclass connection between the capital and the periphery had to go both ways. Just as local commoners were imagined as grateful recipients of appreciation and encouragement from the metropolitan elites, the latter were also to learn from the peripheral laboring classes. The knowledge and traditions of the common inhabitants of Spain's regions were recast as the key to the nation's revival and also to the ability to govern the urban industrial population, pictured as falling prey to proletarian entertainment that degraded its audiences and spread the danger of class warfare. In this mindset, the activities of peasant women received special attention. For example, in 1916 Vega Inclán proposed to create special "tourism zones" around Spain, promoting itineraries that took visitors around to affordable rural hotels. In his words, the state, by means of "efficient propaganda and excursions," must support the owners of these hotels while also promoting the "propensity for living in the country and avoiding the tyranny of populous resort cities with all their inconveniences of high prices and tight agglomerations." Decency, asserted the Royal Commissar, ruled in these modest establishments where "sobriety and the good taste of our race have fortunately chased away luxurious and inappropriate decorations. ${ }^{93}$ In these rural hotels, the food was also 7396.

${ }^{60}$ Report of activities for 1915, AGA Grupo de Fondos 5, Fondo 1.04/1.07, Caja 31/

${ }^{61}$ Storm, The Culture of Regionalism, 140-53.

${ }^{62}$ August 10, 1916, 31.

${ }^{63}$ August 10, 1916, in "Noticia de algunas instancias . . .," 30-31 (AGA Grupo de Fondos 5, Fondo 1.04/1.07, Caja 31/7396). 


\section{Afinoguénova}

deemed irreproachable, "from the cuisine that maintains regional traditions to the service, carried out by peasant women and girls from local areas [comarcas]." ${ }^{94}$ The tourism that the Royal Commissariat encouraged was hence aimed at bringing about social transformation in the cities according to the standards still preserved in the rural communities. And since both nature and taste- be it gastronomic or aesthetic - were found in the peasants' bosom, presenting their lifestyles to urban travelers through promotional efforts seemed equally useful for improving social harmony in the cities and the quality of the tourist experience.

This interest in transforming rural lifestyles into tourist attractions reflected the decades-old Krausista conviction that travel to the country and the revitalization of agricultural communities could become a tool of social engineering. In the tourism experiments of the Royal Commissariat we may therefore distinguish a blueprint of "organic" cross-class connections between the capital and the provinces that were essential for the Krausista views of nationhood as an agglomeration of mutually adjusted parts. But how did this concern fit with the state's nation-building agenda?

\section{TOURISM AND REgIONALISM UNDER DictaToRshiP}

Although Vega-Inclán's tourism proposals did not deal with political integration or the status of different subnational entities, his general agenda of administering tourist attractions from the center while using rural models served the centralism of the Spanish state well. This is why state-promoted tourism and its plans for invigorating the periphery came in handy when Miguel Primo de Rivera's dictatorship started to explore modern approaches to centralization. Among the variety of subnational entities in Spain, it engaged most actively with provinces. ${ }^{65}$

Vega Inclán's commissariat never made a statement about the nature of the "regions" in which it acted, just as nineteenth-century social evolutionists did not define what they meant when they spoke of a "regional Spain." Yet in creating or improving the nation's repertoire of attractions, the commissariat had to cooperate with municipal and provincial governments (Ayuntamientos and Diputaciones provinciales) and at some point was supposed to integrate a Central Junta with local or regional commissions. ${ }^{66}$ When in February 1915 it finally received a modest budget, its first article addressed the demands of "Provincial Delegations

${ }^{64}$ August 10, 1916, 30.

${ }^{65}$ For an analysis of Primo de Rivera's dictatorship and especially its policies of mass mobilization, see Alejandro Quiroga, Making Spaniards: Primo de Rivera and the $\mathrm{Na}$ tionalization of the Masses, 1923-30 (New York, 2007).

${ }^{66}$ Real Orden, 1911. The idea, owing to José Canalejas's initiative, was never implemented after his assassination. 
and support of their respective regions. ${ }^{967}$ The road building that the commissariat helped initiate in order to launch travel itineraries also greatly involved those provinces whose administrations shared the funding for these roads, so the tourist and political maps of Spain soon became indistinguishable. ${ }^{68}$ Thanks to the commissariat's activity, the provinces turned into entities relevant for tourism, each marked by its own unique set of traits. Most important, their limits, mutual connections, and ties to Madrid were also becoming visible.

Touristic reorganization of Spain into provinces can be traced in an important editorial project sponsored by the commissariat: a series of minuscule "PamphletGuides to Spanish Art and History" written in English by the American historian Royall Tyler. These pamphlets were actually excerpts from Tyler's 1909 book Spain: A Study of Her Life and Arts. Focusing on historical kingdoms and cities, however, that earlier book only mentioned provincial subdivisions in passing. ${ }^{69}$ Yet when Tyler's initial text was converted into a series of guidebooks, the information was pieced together according to these administrative units. The guidebooks featured provincial roadmaps, suggesting that each province had its specific history and identity. ${ }^{70}$ The travel routes recommended in these pamphlets departed from the capitals and did not cross the subregional borders, enhancing the provinces' apparent geographical and cultural coherence.

Intellectually, as we know, the commissariat's work was grounded in the evolutionary scheme that viewed the specific characteristics of each subnational entity as a necessary precondition for greater integration. Fostering specialization as well as intranational connections, tourism policy was meant to spur the process of delineating those characteristics. In the 1920s, the word "diversity" was used to describe Spain as a union of culturally specific regions. That conception of the

67 “Art $2^{\circ}$ del presupuesto del Ministerio de Instrucción Pública y Bellas Artes . . . según el acuerdo del Consejo de Ministros de febrero de 1915" (AGA Grupo de Fondos 5, Fondo 1.04/1.07, Caja 31/7396).

${ }^{68}$ AGA Grupo de Fondos 5, Fondo 1.04/1.07, Caja 31/7396, Expediente "Presupuestos: Turismo; Presidencia del Consejo de Ministros; Comisaría Regia del Turismo." A letter accompanying the commisssariat's budget demands for 1916 (Madrid, January 18, 1916, Del Comisario Regio Benito de la Vega Inclán al Excmo, Sr. Ministro de la Instrucción Pública y Bellas artes). In the same letter Vega-Inclán states that he personally established itineraries thinking about provinces.

${ }^{69}$ Royall Tyler, Spain: A Study of Her Life and Arts (New York, 1909).

${ }^{70}$ In many cases adjacent provinces belonging to the same historical region would appear united in one book. See Comisaría Regia del Turismo, Pamphlet Guides to Spanish Art and History (London, not dated): Spain, Salamanca and Zamora; Spain, Tarragona and Lerida; Spain, Avila and Segovia; Spain, León and Its Province; Spain, Barcelona and Its Province; Spain, Burgos and Soria; Spain, Cácers and Badajoz; Spain, Cordova and Jaén; Spain, Toledo and Its Province; Spain, Valencia and Murcia. 
nation was made explicit in the most important publication of the last period in the history of the Royal Commissariat under Primo de Rivera: the guidebook Spain, authored by Francisco Javier Sánchez Cantón. ${ }^{71}$ Like most authors receiving the Royal Commissariat's commissions, Sánchez Cantón was an art historian, the deputy director of the Prado museum. Yet, although his book paid a great deal of attention to Spain's artistic monuments, the author also referenced the themes of tourist development and questions of national integration. He left no doubt about the importance of a unified plurality for the commissariat's mapping of Spain: "If a single word could symbolize the past and present of a nation, that word for Spain would be diversity." 72 In subsequent sections of the book, Sánchez Cantón described the country's geographical variety and the richness of its artistic traditions in a way that directly related the current "diversity" experienced by tourists to Spain's weak territorial integration in the past: "the division between [medieval] kingdoms prevented the fulfillment of national unity; and this individuality, which is a thorn in the side of many a Spaniard, is for the traveler a source of enchantment and delight." ${ }^{\text {73 }}$

Diversity acquired new overtones when the dictator Primo de Rivera made national integration one of his main priorities. Seeking modern ways to consolidate Spanish nationhood, his government did not suppress regional revivals but rather opted for steering local patriotisms in directions compatible with centralization. As part of this program, the administration adopted the course of developing identities for Spain's provinces, which were entities without separatist claims. The map of provinces also had another advantage: with few exceptions, provinces were simple administrative subdivisions within historical kingdoms. This meant that they could be compatible with centralist ideologies without breaking with Spain's centuries-old territorial structure or causing an open conflict with regional patriots. By that time, government officials understood the modernizing impact of tourism and wanted to include it in their collection of innovative nation-building tools. In this new political climate, the social agenda of Vega Inclán's commissariat seemed too centered on art, education, and laboringclass culture while also too imprecise in defining "regions." In 1928, the commissar was removed from the business of tourism policy making (although he was still allowed to run the museums and foundations that he had created) and a new state body, the Patronage Board for Tourism, was born. The government marked its renewed interest in tourism policy by placing the new body under the Presidency of the Council of Ministers (Presidencia del consejo de ministros).

\footnotetext{
${ }^{71}$ Issued in Spanish, French, German, English, and Esperanto (Cal Martínez and Correyero Ruiz, Turismo, 104).

${ }^{72}$ Francisco Javier Sánchez Cantón, Spanish ed., España (Madrid, 1928), 5, English ed., Spain (Madrid, 1926), 7.

${ }^{73}$ Sánchez Cantón, Spain, 22.
} 
Territorially, the work of the board was immediately split between Regional Subdelegations (Subdelegaciones regionales) integrating Provincial Juntas (Juntas provinciales). Additionally, large tourist centers like Barcelona or San Sebastián had Local Juntas. But this seemingly tight structure in reality proved to be chaotic in a way that reflected the ambiguous relationships between localities, provinces, and regions. In a letter answering a question about the names of the entities integrated into Regional Subdelegations dated August 8, 1928 (shortly after the Patronage Board was founded), Secretary General Julio Cavestany announced that the Executive Committee had agreed to call them either "Junta provincial del turismo" or "Junta local."."

Major tourist cities were also provincial capitals, and thus some Provincial Juntas doubled as Local Juntas. Regions, on the other hand, were mapped as associations of provinces. Some of them included more than one medieval kingdom. ${ }^{75}$ This was the case of Levant, which included the provinces of Alicante, Valencia, and Murcia, some of which in the Middle Ages had been parts of the Kingdom of Aragón alongside Catalonia. Thus, although subdividing the territory without much regard for historical borders was a major step toward the cultural recognition of provinces, the entities of tourism administration still seemed to be caught somewhere in between regions and localities.

The partisans of historical kingdoms with well-developed cultural identities welcomed the government's businesslike approach. But they did not fail to publicize their disagreement with the scheme of privileging provinces and "dividing the map of Spain into perfectly capricious and absurd tourism regions." A Galician author denounced the new "regional" map because it suggested that Galicia "ceased being Galicia in order to become a part of two tourism nuclei whose capitals are not in Galicia either." ${ }^{\prime 77}$ The representatives of these arbitrary "regions" did not feel any better about having to promote tourism in provinces with such diverging traditions. In September of 1929, the Subdelegate of the Cantabria Region (which included a mix of Basque, Cantabrian, and Galician provinces), Antonio Quijano de la Colina, refused to promote tourism in the

${ }^{74}$ AGA Grupo de Fondos Cultura (3) Fondo 49(2), Caja 12083. Cal Martínez and Correyero Ruiz also classify the Local and Provincial Juntas as one level of tourism administration (Turismo, 131).

${ }^{75}$ The Basque provinces, for example, were included in the Cantabrian region together with the territories of Galicia, Cantabria, and Asturias but split from the disputed territory of La Rioja. That land was marked as the province of Logroño and included in the Central region together with the provinces of northern Castile. Other regions loosely followed historical kingdoms but lumped together the areas that in the twentieth century adopted differing doctrines of self-determination.

76 “Opiniones: La organización del turismo," El pueblo gallego (Vigo), November 27, 1929.

${ }^{77}$ Ibid. 
Basque provinces. For him, regions had to be subdivided into groups of provinces sharing "ethnic and geographic affinities"- that is, into old-style historical kingdoms. ${ }^{78}$

The Central Junta of the Patronage Board, however, still did not see a problem, or at least refused to see it, insisting that provincial offices could take care of historical kingdoms' identities. Responding to the Subdelegate's demand, the Vice-President of the Patronage Board simply stated that "existing Provincial Juntas should fulfill the above-mentioned mission [of tourism promotion] without needing to create regional Juntas inside each Subdelegation." ${ }^{.79}$ Following this course, the President of the Patronage Board, José A. Sangróniz, came up with a plan that did not reinstate regions but rather strengthened the positions of provincial representatives, who were now to become salaried officials. ${ }^{80}$ In $1928-29$, the Patronage Board's bet on provinces against historical regions thus seemed inviolable. As Ana Moreno Garrido demonstrates, the program of integrating Spain's territory via tourism became visible in the series of propaganda posters that the board designed. These posters featured the names of each province's capital along with place-specific historical, natural, or cultural markers, with references to Spain and the board itself always present in the margins. ${ }^{81}$ With their repetitive framing and their variation only of the province's name and markers, these posters can also be interpreted as a manifestation of the board's firm decision to rearrange the map of Spain by diversified and complementary provinces. From this point of view, the mottoes on each poster ("Valladolid, Spain's Ancient Capital," "Alcalá de Henares, Cervantes's Birthplace, a Renaissance University," "Cádiz, a Door to Europe," "Granada, the Capital of the Caliphs," "Huelva, the Birthplace of America," and so on) served to homogenize Spain's territory, using the techniques similar to current branding in order to devalue traditional regions' claims to uniqueness.

Provincial newspapers welcomed the program and demanded a faster pace, pointing to the link between tourism promotion and the consolidation of provincial ties, especially in the areas without a strong tourist tradition or identity. One commentator from Alicante was shocked to see photographs of some of his city's most spectacular promenades in a prestigious French travel magazine that did not mention Alicante at all - until he realized that one of those promenades was "adjudicated" to Barcelona and another to Málaga, two better-known destina-

${ }^{78}$ AGA Grupo de Fondos Cultura (3) Fondo 49(2), Caja 12110, Actas de reunión del Patronato Nacional del Turismo, September 7 and 9, 1929, 2-3.

${ }^{79}$ Ibid., 3 .

80 "Conclusiones," AGA Grupo de Fondos Cultura (3) Fondo 49(2), Caja 12110, Actas de reunión del Patronato Nacional del Turismo, October 2 and 3, 1929, 12-13.

${ }^{81}$ Ana Moreno Garrido, "Turismo y Nación: La definición de la identidad nacional a través de los simbolos turisticos" (PhD diss., Universidad Complutense de Madrid, 2004), 148. 
tions. ${ }^{82}$ Another author from the same province lamented the total lack of the "moral approximation of its towns and of fraternal spirit" necessary for transforming the area into a "mass of spirits pulsating in unison under one canopy" that the concept of a province seemed to require. ${ }^{83}$ His solution? "Do a better job of attracting tourism."

The provinces were thus gradually discovering the magic of tourism that could put them on the map. But the days of Primo de Rivera's province-based centralism were numbered. At the end of January of 1930 the dictator resigned, and the king charged General Dámaso Berenguer with forming a new government. Soon after, the Patronage Board failed an audit and had to restructure. ${ }^{84}$ One level of its Juntas had to go, sparking a debate about the central government, the role of the Patronage Board, and its relation to provincial administrations. No one seemed to know whether Spain's next territorial reorganization would pay more attention to provinces, as the dictatorial regime had done, or return validity to historical kingdoms. How provincial tourism policy would be defined and who would be in charge of it were the most interesting topics of the ensuing discussions. The Patronage Board polled the members of its own Executive Junta and the representatives residing in the regions about their preferences. Their answers demonstrated that the former (based in Madrid) fully subscribed to the policy of suppressing the regions in favor of provinces administered from Madrid, while the latter did not. Several regional representatives stated that the Provincial Juntas should be abolished and only regional ones should stay. Their written reports depicted Provincial Juntas as useless and underfunded structures that served neither regions nor localities. ${ }^{85}$ However, what the Executive Committee in the

${ }^{82}$ La voz de Levante, January 1930. AGA Grupo de Fondos Cultura (3), Fondo 49(2), Caja 12239, Expediente "Alicante": "While our city has its beauty in huge disregard, our photographs are used to advertise other cities' attractions and lure tourists in. Or at least this is what happened in the magazine 'Les Grandes voyages', which, singing praises to Barcelona, the beauty of the Mediterranean and the most cosmopolitan of its cities, has attributed to it the most beautiful stretch of our Paseo de los Mártires as if it were located in Barcelona, and renamed it into 'Paseo de Colón'. And, as if that were not enough, in the section dedicated to Málaga, the author attributes to this beautiful city the gorgeous view of our Paseo de Gomiz from the garden of Baroness de Satrústegui, giving it the name of . . . Reading $[$ sic $] . "$

83 "Hay que realizar una labor de atracción," La voz de Levante (Alicante), January 1930. AGA Grupo de Fondos Cultura (3), Fondo 49(2), Caja 12239, Expediente "Alicante": "Es duro confesarlo, pero la realidad obliga a ello: la unidad de la provincia alicantina, la aproximación moral de sus pueblos y el espíritu de hermandad necesarios para que toda esa zona que la división política y administrativa de España designó con en nombre de Provincia de Alicante, sea una masa en la que todos los espíritus vibren cobijados bajo el mismo dosel, no existe, y si existe, duerme un sueño cada vez más peligroso.”

${ }^{84}$ Cal Martínez and Correyero Ruiz, Turismo, 167-71.

${ }^{85}$ AGA Grupo de Fondos Cultura (3) Fondo 49(2), Caja 12083, Informe del Subdelegado de la Región de Levante a Julio Cavestany, March 11, 1930. 
center deemed expendable were not the Provincial Juntas but rather the Regional Subdelegations themselves.

Spain's postdictatorial government also seemed to doubt which subnational structure it should now support. The Royal Order of the Council of Ministers adopted on July 5, 1930, stated that the restructured Junta of the Patronage Board would act only on two levels, central and provincial, ${ }^{86}$ while at the same time promising that "provincial organization would fit the touristic situation of Spanish regions and provinces." ${ }^{.87}$ The decree charged the Junta of the Patronage Board with determining the best way of coordinating the needs of regional and provincial tourism. ${ }^{88}$ With or without reason, this organization interpreted the order as a mandate to suppress provincial representatives, ${ }^{89}$ so it came up with a plan that ended up sending mixed messages about Spain's map. While it did eliminate three Regional Subdelegations (Central, Catalonia-Aragon-Balearic Islands, and Western), it merely renamed the remaining ones as "Delegations," suggesting that they might receive greater autonomy. Additionally, the suppressed Subdelegation of the Catalonia-Aragon-Balearic Islands was replaced by three new entities, each responsible for one historical kingdom as well as for the provinces comprising them. Only the provinces of two other suppressed structures, the Central and the Western Subdelegations, were now lacking a regional intermediary and had to operate directly under the Central Offices. ${ }^{90}$ This was an ambiguous plan that nominally recognized the provinces as the subject of the state's tourism policy while in actuality downgrading them to subdivisions of medieval kingdoms.

The 1930 restructuring also gives us a glimpse of the postdictatorial attempts to reestablish connections with traditional patriotic associations and businesses by reaching out to local developers. The Royal Order cited above suggested that local tourism syndicates and other bottom-up associations could assume some of the Patronage Board's responsibilities for provincial tourism. ${ }^{91}$ Some of these

86 “Esta organización administrativa (La Junta del Patronato) se dividirá en Central y Provincial." Real Orden no. 398 de la Presidencia del Consejo de Ministros, July 5, 1930, Gaceta de Madrd, no. 187, July 6, 1930, 173.

${ }^{87}$ Real Orden, July 5, 1930, Art 4.

${ }^{88}$ Ibid., Art. 5.

${ }^{89}$ AGA Grupo de Fondos Cultura (3) Fondo 49(2), Caja 12111, Acta de la reunión celebrada por el Comité Directivo y Ejecutivo del Patronato Nacional del Turismo, en su domicilio social, en Madrid, con fecha, July 15, 1930, 2.

${ }^{90}$ AGA Grupo de Fondos Cultura (3) Fondo 49(2), Caja 12111, Acta de la reunión de las Juntas Directiva y Ejecutiva del Patronato Nacional del Turismo, July 21-22, 1930, 2-3.

${ }^{91}$ Real Orden, July 5, 1930, Art 4: "La organización provincial se acomodará a la situación turística de las regiones y provincias españolas, actuando el Patronato, directamente, bien por medio de los sindicatos de Iniciativa, Asociaciones para la Atracción de Forasteros, Comisiones de Monumentos u otras Entidades o personas que, a juicio de la Junta, se consideren capacitadas para desempeñar esta misión.” 
groups dated back to times before state-run tourism and did not support its centralist agenda, so this did not comport with their local interests. Although the Junta indeed negotiated the prospect of transferring the representation of provincial tourism, Barcelona's anti-centralist Sociedad de atracción de forasteros offered conditions so complicated that the board decided to keep its own delegate in the area. ${ }^{92}$ Local tourism developers seemed to have diverging opinions about the Patronage Board's rapprochement to their activities and agendas, especially in places with greater separatist claims.

On the other hand, whenever these negotiations succeeded, provincial administrators were not amused, feeling that they were losing an important and only recently acquired ally. In December of 1930, the delegates to the Assembly of Provincial Administrations (Diputaciones provinciales) demanded that the new Patronage Board take into account their interests and include their representative, appointed by the Assembly's Executive Committee. As to the work in the provinces themselves, the delegates proposed to transfer the functions of the Patronage Board's provincial Juntas not to local commercial associations, but rather directly to state authorities, "which will do this service in the best way possible, following, of course, the indications from the Patronage Board's Central Junta." Clearly, for the provinces, state-run tourism was approaching the point of being a branch of centralized administration. Yet if in 1930 Provincial Administrations were still hoping to obtain political and economic benefits from tourism, supporting the provinces would very soon cease to be an issue. In April 1931, the king fled to France and the Second Republic was proclaimed. The Patronage Board resigned in haste. By the end of the year it had been reinstated and continued its work, but at that time the centralist agenda was to be abandoned or, at least, substantially reconfigured.

\section{"Errevolution": Centralism, Regionalism, and Food for Tourists}

The story of how the nineteenth-century appreciation of lower-class regional cultures eventually strengthened Spain's provinces is perhaps best exemplified by the changing perceptions of regional cuisines. The representations of Spanish

\footnotetext{
92 AGA Grupo de Fondos Cultura (3) Fondo 49 (2), Caja 12111, Acta de reunión del Patronato Nacional del Turismo, September 13, 1930, 10.

93 "Que al reorganizarse el Patronato Nacional de Turismo ..., se tengan en cuenta los intereses que en este orden ostentan las Diputaciones provinciales y se incluya una representación de las mismas en el referido organismo, que recaerá en la persona que designe el Comité ejecutivo de la Asamblea de Diputaciones de régimen común, y que las funciones desempeñadas por las juntas provinciales del Patronato Nacional del Turismo sean transferidas a las Diputaciones, las cuales desempeñarán el servicio en la mejor forma, de acuerdo, desde luego, con la Junta central del Patronato" ("La asamblea de diputaciones provinciales," $A B C$ [Madrid], December 2, 1930, 25).
} 
food followed the nation-building agenda of the Spanish state and traversed the same phases: the vague Krausista regionalism, the "diversity" of the early 1920s, a brief period of exaltation of provincial cuisines at the end of the 1920s, and a return to culinary regionalism, albeit of a modern sort, in the 1930s. As a result of these shifts, by the early 1930s a new map of a nation of culinary regions was born. Unlike their nineteenth-century predecessors, those who were now writing about food would firmly acknowledge that for the typical dishes to subsist, cooks needed trucks and patrons, automobiles and hotels. In order to determine how much such a process had to do with the agenda of state-run tourism, we must look at how these changing attitudes toward food related to nation building and centralism.

Spaniards owe the first printed debate in their language about gastronomy and regionalism to José Castro y Serrano, a Krausoinstitucionista from Giner's immediate circle, and his friend the philologist Mariano Pardo de Figueroa. ${ }^{94}$ In 1888 the two authors anonymously published A Modern Table; Letters about the Dining Room and the Kitchen Exchanged by Dr. Thebussem and His Majesty's Chef.$^{95}$ Their book - a compilation of articles that had appeared between 1876 and 1883 in La ilustración española y americana - examined, under the allegorical guise of "the modern table," the staple Krausista repertoire: self-government, civil liberties, and territorial unity. Castro y Serrano had strong political opinions. For example, in a letter eloquently titled "Free Table in a Free State," ${ }^{\prime 96}$ he analyzed the relationship between dinner hosts and guests in terms of a social contract and demanded that guests be given fair representation. As for Spain's territorial integration, he criticized the "anarchy" and "federalism" reigning in the country's kitchens and articulated the aim of achieving "national gastronomic unity." It is significant that His Majesty's Chef proposed to unify Spain by collecting and publicizing information about local cuisines and having rich people embrace humble peripheral dishes. These were metaphorically compared to the regional law codes (fueros) that were at the time viewed as the main obstacle to national integration. For Castro y Serrano, local privileges were best "attacked ... by popularizing them rather than snatching them away. There is hardly a locality [comarca] in Spain that doesn't have a special dish worthy of appearing on the palace tables. Let us ask each of them for a recipe and let us

\footnotetext{
${ }^{94}$ The precedent was set by Alexandre Dumas's Grand dictionnaire de cuisine (Paris, 1873).

${ }^{95}$ La mesa moderna, cartas sobre el comedor y la cocina, cambiadas entre el Doctor Thebussem y un cocinero de S.M. (Madrid, 1888). Castro y Serrano acted under the alias of "un cocinero de S.M." and Pardo de Figueroa used the identity of an imaginary German scholar, "Doctor Thebussem."

${ }^{96}$ Originally appearing as "La mesa libre en el Estado libre," Ilustración española y americana, July $30,1877,6$.
} 
create a repertoire of famous Spanish dishes. ${ }^{.97}$ In the language of evolutionary regionalism, this meant that local and lower-class habits were the prime components of national culture, which the elites residing in the capital had to protect, collect, and synthesize rather than suppress.

In the early twentieth century, the female writers Emilia Pardo Bazán and Carmen de Burgos brought a gender dimension into this debate, authoring cookbooks specifically designed for Spanish women. ${ }^{98}$ Yet when state-run tourism was born in Spain and began to rely on the Krausista mindset, male authors took the lead in determining the regional and class dynamic of food. In the guidebook Spain (1925) mentioned earlier, Francisco Javier Sánchez Cantón cited only His Majesty's Chef (Castro y Serrano) - and not any of the best-selling cookbooks by women authors - among his predecessors. ${ }^{99}$ That did not mean, of course, that he simply repeated nineteenth-century ideas. Writing during the early years of Primo de Rivera's dictatorship (but before the Patronage Board began to prioritize provinces over regions), he steered the Krausista populist collectionism toward diversity. In opposition to Castro y Serrano's 1888 lamentations, he did give an example of a national dish: the stew (cocido). But what allowed him to define it as national was not its uniformity across the country's territory. Rather, the stew, in his words, was national because it existed all around Spain yet also admitted variations, having "at least as many forms as there are regions." ${ }^{100}$ The modified versions of the dish, the author asserted further on, sometimes differ so substantially 'that they lose the name 'cocido' and are called 'olla podrida' - powerfulin the mountains of Santander; . . . it is called 'pote' in Asturias and 'caldo' in Galicia." ${ }^{101}$ This was not a predictable choice for a quintessential national dish.

${ }^{97}$ La mesa moderna, 180.

${ }_{98}$ Emilia Pardo Bazán, La cocina española antigua (Madrid, 1913), and La cocina española moderna (Madrid, 1914); Carmen de Burgos, La cocina moderna (Valencia, 1906), ¿Quiere usted comer bien? (Barcelona, 1916), Nueva cocina práctica (Valencia, 1925). For Carmen de Burgos, I follow the dates provided in Ingram, "Spain on the Table," 143 (Ingram uses Lynn Scott's analysis).

${ }_{99}$ Sánchez Cantón, Spain, 83. Sánchez Cantón also had at his disposal a long tradition of culinary musings by foreign male travelers to Spain, described by José Ruiz Mas, among others ("Costumbres culinarias, refranes gastronómicos, ollas, pan y gazpachos en los libros de viajes de Richard Ford y George Borrow: Un esbozo de la España hambrienta del siglo XIX," in La Andalucia rural vista por viajeros extranjeros: Campos, posadas y tabernas, ed. Vicente López Folgado and María del Mar Rivas Carmona [New York, 2013], 33-60). As Ingram points out (266), Sánchez Cantón's readings of regional cuisines were later cited in Gregorio Marañón's 1929 "Prólogo: Breve ensayo sobre la cocina española" (Cocina española y cocina dietética [Madrid, 1929]). The dominant debate concerning national food thus completely avoided the best-selling contributions by female authorsa result consistent with Roberta Johnson's discussion of Spain's gendered nationhood in Gender and Nation in the Spanish Modernist Novel (Nashville, TN, 2003).

${ }^{100}$ Sánchez Cantón, Spain, 84.

${ }^{101}$ Ibid. 
But it was one that pointed to an interesting phase in tourism-driven territorial reorganization, still vague in its understanding of regionalism: the "diversity" phase.

The lack of a gastronomic center in Sánchez Cantón's presentation was also more consistent with nineteenth-century Krausista evolutionism than with twentieth-century centralism. Sánchez Cantón presented the Madrid variety of the stew as a regional dish ("the 'cocido' of Madrid") alongside other regional dishes, thus showing no sign of a centralizing effort. Rather, his guidebook drew a picture of infinite culinary variations either without a center or centered in the peripheral land of Cantabria, which at the time was considered the land that saved Spain's nationhood from the eighth-century Arab invasion. Sánchez Cantón calls Cantabria "a region which represents the sum total of regional products, for it contains beef, ham, black pudding, sausage, chicken, potatoes, greens." ${ }^{102}$ In a similar vein, he emphasized that the variety of regional cuisines depended on the local origins of components: "Each one of the famous ingredients must come from a certain locality to be succulent; thus the ham will be from Avila, Villalba, Trevelez, Jabugo, or Monsánchez; the sausages from Cantimpalos, Candelario, or La Rioja; the potatoes from Monforte or Ariza; beans from Barco de Avila," and so on. ${ }^{103}$ In other words, just as in France, this regionalism relied on the authenticity of subregional local terroirs for its appeal.

This was no longer the case in the gastronomic guidebook written in 1928 by Dionisio Pérez (under the pen name "Post-Thebussem") at the National Patronage Board's request and published in 1929. Like Sánchez Cantón, Pérez explicitly cited Castro y Serrano and identified the stew as Spain's national dish. Yet he insisted on calling it, in a centralist way, the "Madrid stew [cocido madrileño]": "Castro y Serrano was wrong. The Madrid stew represents the synthetic formula of all Spanish stews; with the spirit of equality characteristic of the people of Madrid, it knows how to become grand or humble according to each table's grandeur or humility." 104 The author added two more national foods: garlic soup (sopa de ajos) and Vizcay-style cod (bacalao a la vizcaina). What is interesting, in view of the state-run tourism agenda of the late 1920s, is how he explained the origins of these dishes. Just like his predecessors, Pérez believed in diversification, and so national food does not appear as foundational but rather as evolutionary. But here is the intriguing difference: while the nineteenth-century social reformers exalted education rather than commerce and set their hopes on the lower-class rural rather than the upper-class urban population, in Pérez's exposé all these priorities are turned inside out. According to him, Spaniards owed the

102 Ibid.

103 Ibid., 84-85.

104 Dionisio Pérez, Guía del buen comer español: Inventario y loa de la cocina clásica de España y sus regiones (Madrid, 1929), 284. 
ubiquity of their "national dishes" to the café and restaurant cultures of Madrid. Centralized in their establishments, meals only became national because they were reimported into the provinces along the routes of nineteenth-century trade. Pérez's modern narrative made it seem as if there was no longer a need to popularize rural cuisines because urbanization had already taken care of it.

For Pérez, Madrid became a gathering spot for Spain's regional cuisines because it was an administrative center: it housed the royal court that made it "the great melting pot where all of what we call 'national cuisine' was forged, cast, and unified." 105 But what was this national cuisine? In the beginning, there was nothing but a collection of homemade dishes following the tastes of people who had to spend some time in Madrid. There were no home kitchens for these people in Madrid. But, Pérez continued, there were taverns and restaurants. Wishing to cater to all clients and meet all demands, their owners managed to synthesize multiple gastronomic preferences, thus making Madrid the national gastronomic center. Eventually, the cuisine of Madrid started to radiate outward and diversify in every region. For example, Pérez traced the modifications of the garlic soup developed by the tavern owners in Madrid based on the traditions of Andalucía, La Mancha, and the Alto Aragón. According to the writer, the version of this soup that could be found in his time was no longer the result of the disjointed pasts of each of these places. Rather, it had acquired national status after the multiregional garlic concoction from Madrid was reimported back into the country's peripheries. Just as in Sánchez Cantón's Spain, the gastronomic theory in Pérez's guide interpreted "diversity" as a modern and consumable form of national unity that had overcome the previous stage of disintegration.

Most crucially, while Pérez classified prenational foods by regions, he seems to attribute their reimported national varieties to provinces. Thus, in this story, prenational dishes had only "regions" as reference points: "the common people .. . were bringing to Madrid the taste and the ways of the regions of their origin." Conversely, "provinces" were their new destinations: "Having left Madrid, garlic soup, which is already a national dish, becomes modified. In some localities in the Segovia province ... people add cumin and toast garlic in the oven. In some coastal provinces these soups are made ... adding to them fish and seafood. . . . In La Rioja, they add tomatoes and fresh peppers. . . . In Basque provinces, whose inhabitants profess a sacred horror of paprika, ... [a] fair amount of tomato paste is added to garlic soups. Something similar happens to the Madrid stew."107

Here, therefore, was the recipe for culinary nationhood: national dishes were those that were made in the center from multiple regional sources, brought back into the regions, and then had local elements mixed in to become provincially di-

105 Ibid., 277-78.

106 Ibid., 277.

${ }^{107}$ Ibid., 281-82. 
versified. Several inconsistencies in this story, however, suggest that underneath the deft picture of synthesis and diversification things were still unresolved. Pérez used the name of the historical kingdom, and not the province, to name La Rioja. This reference reflected the fight for political recognition of this historical entity, which in 1929 was administratively subsumed in the Logroño province. "Basque provinces," to which the author attributed common ways of cooking, also appeared united without any provincial variation. Alongside these uncertainties one fundamental question also remained unanswered: why would anyone recognize as one dish (garlic soup in Pérez's classification) something that in different areas of Spain was actually a fish stew, a seafood soup, or a tomato concoction? In 1925, Sánchez Cantón had given the right of gastronomic self-determination to those foods that had diversified to the point of acquiring another name. Conversely, in Pérez's 1929 rendering, the agenda of unity glossed over the differences.

The narrative about how national food, to repeat Pérez's tellingly industrial metaphor, was "forged, cast, and unified" is also a story about important shifts in gender and class roles. If industry and commerce were responsible for producing national cultures by appropriating the traditions of regional home cooking, then it was men working outside their homes who were taking the lead. And since regional agency was now reduced merely to varying models furnished from the center, women's activities were becoming secondary, subordinated to the centralizing industrial efforts and imitative. Such a deemphasizing of women's labor in creating culture mirrored the policy's tendency to hijack rural cultures by collecting, classifying, and redistributing information about peasant lifestyles and artifacts and claiming them as a source for the centralized culture. Hence, paradoxically, tourism-driven identities undermined the activities and roles of peasants and women while remaining dependent on them for raw materials.

Books such as Pérez's provided a framework for modernizing the perceptions and social roles of regional home cooking, but the reality of cooking for tourists was something different. Certainly these were no longer times when hungry travelers had to fetch their own beef in the hope that the innkeeper's wife would agree to cook it. ${ }^{108}$ But in 1928, those coming to eat at Spain's hotels still had to know enough French to order their "goujons de sole frits," "solomillo Richelieu," veal "noisettes chasseur," or "purée de pommes" featured next to Spanish beans from La Granja or chicken fried in its own juice. ${ }^{109}$ In 1929, the Patronage Board

${ }^{108}$ As described, among others, by Théophile Gautier in Voyage en Espagne (1840) (A Romantic in Spain, trans. Catherine Alison Phillips [New York, 2011], 14).

109 “Consommé Frío o Potage, Goujons de Sole Frits, Solomillo Richelieu, Pollo Asado al Jugo, Ensalada, Judías de Granja Salteadas, Glace Marquise, Gateaux, Quesos, Frutas" (Madrid, Hotel Florida, Comida, July 18, 1928); "Entremeses Variados, Huevos Revueltos Portugueses, Mero con Guisantes, Noisettes de Ternera Chasseur, Purée de 
tried to create precedents for serving Spanish food in the hotels that it managed. Predictably, the two hotels selected for this endeavor were in the vicinity of Madrid: the Parador de Gredos and the Hostería del estudiante en Alcalá de Henares. The latter, created in 1929-30, was a historically themed eatery representing a sixteenth-century Castilian "mesón." It advertised itself as featuring "exclusively Spanish cuisine"; young women wearing traditional dress served the dishes on artisanal plates from Talavera de la Reina. ${ }^{110}$ The concept catered to several political agendas: the interest in historical revival, the exploration of regional crafts, and the variety of Spanish nationalism in which Castile stood in for Spain. Local enthusiasts liked the idea to the point of lamenting that the University of Alcalá de Henares had not fully invested itself in the subject and had not created a department of "Castilian cuisine" instead of one dedicated to "juridical literature." 111 The timing of the Hostería's inauguration (in May 1930, after the end of Primo de Rivera's dictatorship) meant that the restaurant's mixture of regionalist, centralist, and provincial ideologies was no longer an issue.

It proved to be much harder to reorganize the menu offerings at the Parador de Gredos. In 1929, Spain's first state-run hotel (inaugurated in 1914) was intended to become a flagship of modern tourism and was closed for a complete makeover. Its kitchen also had to be fully refurbished and a new cook had to be hired. But the work went slowly, and by the spring of 1930, when the restaurant was ready to begin reorganizing, the Patronage Board had already abandoned its province-based centralism. The representative of the Patronage Board overseeing the hotel's refurbishment then simply sought a way to offer "appropriate dishes, always from the Spanish cuisine, which is what we want." ${ }^{\text {"12 }}$ In practice this meant that a new cook had to be found, either in the area (in small towns and villages between Salamanca, Plasencia, and Ávila) or in Madrid. The manager's correspondence demonstrates that the new cook had to be a woman. Apparently, Spanish kitchens did not live up to the Patronage Board's gastronomic propaganda: Pérez's guidebook may have represented national cuisine as a modern industrial process, but in reality professionally trained male cooks knew only the standard French-style cuisine, and Spanish dishes continued to be homemade. So finding a chef who could make Spanish food alongside pastry (a staple needed to

Pommes, Chuleta de Cordero Grilles [sic], Ensalada, Profiteroles au Chocolat, Quesos, Frutas" (Madrid, Hotel Florida, Almuerzo, July 18, 1928) (AGA Grupo de Fondos Cultura (3), Fondo 49.2, Caja 11987, Expediente "PNT").

110 "Los señores de Clementel en la Hostería del estudiante," La Época (Madrid), June 2, 1930.

${ }^{111}$ J. J. de Lecanda, "Hostería del estudiante,” El Nebrón (Bilbao), May 28, 1930, “El Patronato nacional del turismo en acción." AGA Grupo de Fondos Cultura (3), Fondo 49(2), Caja 12239, Expediente "Alcalá de Henares."

${ }^{112}$ Letter from Enrique Cavestany to Inocencio Arobes, March 12, 1930. AGA Grupo de Fondos Cultura (3), Fondo 49(2), Caja 11989, Expediente "Parador de Gredos." 
satisfy foreign guests) proved all but impossible. There were no men for the job, and women who cooked Spanish dishes on a daily basis were presumed unable to run a professional kitchen. When the manager failed to locate a chef in the vicinity, the Patronage Board proposed to hire someone in Madrid who could teach a prospective female chef how to cook. That did not work either. So Enrique Cavestany, the representative of the Patronage Board, announced in Madrid an open competition to fill the opening. The inauguration of the Parador had already been scheduled, and the deadlines were tight. Who would cook for the guests until the competition was over and a new cook hired? The board's solution was telling: employ a woman who was not a professional cook (she was in charge of the hotel's bedding) but whom Cavestany remembered as the "one who fed us so well." ${ }^{\prime 13}$ In other words, in order to offer the visitors Spanish dishes, the Patronage Board had to seek help from an old-style home cook. Indeed, while the board kept trying in vain to find a professional chef through its competition in Madrid, she did cook for the first visitors. Eventually it was the local manager who found a better candidate: a female chef who knew about Spanish dishes as well as desserts, who cooked for a family in Madrid but had relatives in a town near the Parador. She demanded a rather high wage of 100 pesetas per month; the manager who hired her was only making 300 . Historical sources do not reveal whether she was hired, because in mid-May the Junta of the Patronage Board decided that the Parador needed a private manager. But the menus dated May 24 and 25 indeed featured a whole array of simple Spanish dishes ranging from the Spanish omelet ("tortilla de patata") to chicken rice and flan. From over a dozen choices, only one, "crema San Germain," was reminiscent of anything French, but it was a creamed pea soup by that time well known to Spaniards. ${ }^{114}$ Just as in Alcalá de Henares, young women serving the food wore regional dress.

This story gives us a glimpse of the real progress of Spanish national cuisine. The tourism administrators were working hard on branding dishes and making them publicly available, but professionally made Spanish food was not easy to come by. In the meantime, women who knew how to prepare Spanish dishes were excluded from the male-driven gastronomic nationhood, or simply were in no rush to trade their home stoves for industrial kitchens. These attempts to merge culinary nationalism and tourism show that it was much easier to standardize food than to make it according to the new precepts. This is also why available sources

\footnotetext{
${ }^{113}$ Letter from Enrique Cavestany to Inocencio Arobes, April 2, 1930. AGA Grupo de Fondos Cultura (3), Fondo 49(2), Caja 11989, Expediente "Parador de Gredos."

114 "Crema San Germain, Truchas Fritas, Jamón York con Patatas, Ternera Brezada al Jugo, Judías Salteadas, Flan de Limón, Queso, Frutas" (Comida, May 24, 1930); “Sobremesas variadas, Tortilla de Patatas, Judías Fritas, Arroz con Pollo, Chuletas de Ternera, Patatas Chips, Pastelería, Quesos, Frutas" (Almuerzo, May 25). AGA Grupo de Fondos Cultura (3), Fondo 49(2), Caja 11989, Expediente "Alojamientos. Ofertas. Parador de Gredos.”
} 
do not point to any practical correlate of Pérez's "provincial" cuisines having been implemented by the Patronage Board. Spain's tourist restaurants had their timers set for a longue durée of transforming domestic meals into an art able to withstand the French challenge. And so, by the time tourism administrators got around to creating gastronomic propaganda, provincial identities were no longer a priority, while regionalism and nationhood still were. Cooking Spanish food from local ingredients also meant that the managers had to deal with the difficulties of adjusting typically female or rural activities to urban needs. Regional and national interests were merging in hotels' kitchens, while the harmony between town and country was slow to come.

Gourmands in the regions, however, understood quickly and well the potential for preserving or creating local dishes. In July of 1930, Jokintxo Ilundain, a writer from Pamplona, declared that his were the times of a culinary "errevolution" provoked by erratic people and revolving wheels: "tourism and trucks, together with the new fad for rural life and the rural and civic mercantilism, have changed completely . . . that precious sector of regional arts that has a kitchen aroma to it." 115 Trucks, tourism, money, and regional food have been riding together ever since.

\section{Conclusions}

The narrative recounted above helps us to understand how tourism could reinforce a succession of nation-building agendas, ranging from the Krausista-inspired regionalism steeped in the elites' revalorization of popular culture to Primo de Rivera's province-based centralism to a return to regionalism in the early 1930s. One can also distinguish in early tourism planning the concerted efforts of the upper and middle classes, either in Madrid or in the periphery, working with the government on redesigning the national territory. Sometime around 1910, the Marquis de la Vega-Inclán steered the state's efforts in the direction of a project for an "organic" society grounded in wisely appropriated rural lifestyles. Rooted in this reformist program, tourism became something more than merely a centralist revision of early regional tourism efforts. It was a reform agenda, an ideology, and a practice concerned as much with generating peripheral loyalties as it was with integrating them into a centralized whole. And while its results hinged on the nation-building options that different governments proposed, they were also consistent with the evolutionary approach to nation making shared widely by social groups that at times opposed one another. For these people, tourism was producing a cultural nationhood whose integration relied on modern ways of

115 Jokintxo Ilundain, "La buena mesa y la cocina clásica de Navarra," Diario de Navarra (Pamplona), July 7, 1930, 99. AGA Grupo de Fondos Cultura (3) Fondo 49(2), Caja 12270, Expediente "Navarra." 
doing politics. An interesting part of this story is, of course, the unusual versatility of such a tourism-driven regionalism. Owing its initial impulse to the quest for the popular roots of self-government and nationhood, it ended up being equally compatible with the dictatorial road to modernization and with the decentralization that took place under the Second Republic.

In my analysis, tourism offered a productive model for transforming political regions into coherent cultural communities because it provided an effective link between national and local patriotisms. Its promoters, metropolitan residents, did not forget their native lands but rather rewrote them from the center as distinct parts of the nation's whole. They viewed Spain as a tourist destination that was tied together by virtue of its diversity, incorporating high and low cultural forms, history and landscape, architecture and food. In their efforts to map the nation, Spain's officials and intellectuals came up with an outline resembling the "complementary difference" of the centralized French regions embodied in regional cookbooks and in the Michelin guides that Harp and Ferguson have studied. In France, however, such a consumable diversity emerged against the background of a full political integration, to which it added an attractive cultural twist. The opposite was true in Spain, where the state tried to use tourism-triggered cultural identifications to facilitate political integration. Hence, while in France diversification was mostly the work of private businesses, in Spain it was a matter of government concern, and while in the former diversification was a modern spinoff of nation building, in the latter it was seen as yet another road to nationhood.

The final question to be asked is, did these policies work? In other words, did tourism-driven cultural identities elicit the same strong sense of belonging as Spanish "small motherlands" and historical kingdoms did? In order to answer this question, we should clarify that, as with all regionalisms, its "touristified" forms represented the views of an elite and only addressed the masses through the prism of social reformism. Future inquiries into the effects of this form of regionalism should not only examine the texts written by policy makers but also investigate how, if at all, peasants and urban proletarians reacted to upper-class attempts to collect and then redistribute their daily habits (or those of other communities) as identities, be they regional or provincial. Some things, however, can already be said about the outcomes of this form of regionalism. As my analysis has demonstrated, early tourism policies were negotiated between business communities, the state, and an array of intellectuals residing in Madrid but coming from Spanish peripheries. As such, their documents allow us to see whether the identities that they were creating had any relevance for these social groups. The clashes between the Royal Commissariat and regional developers, for example, demonstrate that people living in the regions welcomed staterun tourism just as much as they protested when the state tried to break longstanding regional loyalties and transfer them to the provinces. On the other hand, even the brief period of tourist branding of Spain's provinces was enough to 
elicit strong support from provincial authorities. When the program was abandoned, these authorities were more eager to see tourism as a branch of administration than they were to cooperate with business associations, many of which were steeped in old-style allegiances to historical kingdoms.

Tourism would again become useful to the center under the dictatorial government of General Francisco Franco, when it was mobilized to counter peripheral nationalisms in the 1960s. The times called for softer means of keeping the nation united, while tourists were relocating to the beaches. Consequently, in 1964 the Registry of National Geo-Touristic Destinations, created by Manuel Fraga Iribarne's Ministry of Information and Tourism, launched the process of renaming and reconfiguring large parts of Spanish territory by "coasts": Costa Brava, Costa del Sol, Costa de la Luz, and so on. As I remarked elsewhere with Jaume Martí Olivella, "such a geographical terminology contributed to the Francoist process of the internal erasure of cultural differences" by making the regions' traditional names irrelevant. ${ }^{116}$ Could one interpret this development as regionalist as well? And how did the post-Franco map of Spain divided into autonomic communities, each with its own tourism department, fit into this story? Further inquiries into the intersections between regionalism and tourism in other epochs and countries should help us answer this question.

The era of coastal tourism transformed Spain into a "paella nation" in the eyes of foreigners. Modern Spaniards, in the meantime, remain faithful to the "Spanish omelet," which was not yet branded as "Spanish" at the time studied in this article. Conversely, they would never cite as national the stew, currently a local marker of Madrid; the Vizcay-style cod, considered a Basque dish; or the garlic soup, whose main ingredient turned out to be a common denominator so small and ubiquitous that it has found no terroir of its own.

${ }^{116}$ Eugenia Afinoguénova and Jaume Martí-Olivella, “A Nation under Tourists’ Eyes: Tourism and Identity Discourses in Spain," in Spain Is (Still) Different: Tourism and Discourse in Spain, ed. Eugenia Afinoguénova and Jaume Martí-Olivella (Lanham, MD, 2008), xxxvi. 